\title{
Socio-ecological Impacts of Water Hyacinth (Eichhornia Crassipes) Under Dry Climatic Conditions: The Case of Shagashe River in Masvingo, Zimbabwe
}

\author{
Chapungu L*, Mudyazhezha OC and Mudzengi B
}

Great Zimbabwe University, Department of Physics, Geography and Environmental Science P.O Box 1235 , Masvingo, Zimbabwe

*Corresponding Author: Chapungu L, Great Zimbabwe University, Department of Physics, Geography and Environmental Science P.O Box 1235, Masvingo, Zimbabwe, Tel: 0772248931; E-mail: 1chapungu@gmail.com

Received: 25 January 2018; Accepted: 07 February 2018; Published: 12 February 2018

\begin{abstract}
In Zimbabwe, aquatic environments continue to endure water hyacinth (Eichhornia Crassipes) invasions. The intricate and distinctive characteristics of water hyacinth make it one of the most ecologically resilient aquatic plants enabling it to invade major water systems. There is still paucity of scientific knowledge about the social and ecological ramifications of this macrophyte. In this study, we assessed the social and ecological effects of water hyacinth along Shagashe River. The mixed methods research design was adopted as the strategy of inquiry. Sampling sites were selected to compare two environments along the river, one under the cover of water hyacinth and the other without water hyacinth. Moreover, the sampling was done in two distinct periods i.e. the dry season and wet season. In each of these sections and periods, 15 sampling points were selected using the stratified random sampling criteria. Ecological data for the two sections were compared by means of one way analysis of variance (ANOVA). A comparison was also done on the social data from the two sections of the river and also from the two seasons. Ecological data was collected mainly through field measurements of biodiversity, sedimentation rate and velocity. Laboratory testing of evaporation rate and water parameters augmented the ecological data collection processes. Data on sociological aspects was collected mainly through interviews, questionnaire surveys and the story telling approach. Results show that the water hyacinth infested environment had low phytoplankton productivity, low dissolved oxygen, high sedimentation rates, high water loss and reduced river velocity among other ecological
\end{abstract}


effects. Communities have been affected through lack of access to debris free water, reduced access to water points, reduction of fish catch and clogging of irrigation pipes. We conclude that water hyacinth has significant socioecological ramifications along Shagashe River. There is need to identify and exploit potential opportunities provided by the presence of water hyacinth such as biogas production, use as animal feed and use as raw material for the craft industry in order to convert the water hyacinth socio-ecological "curse" into a "blessing".

Keywords: Water hyacinth; Social and ecological effects; Shagashe River

\section{Introduction}

Half of the world's rivers are heavily polluted and most of them run through developing countries [1]. In most less economically developed countries, sewer systems usually draw untreated sewage into rivers. This is due to the fact that most developing countries cannot afford to build waste treatment plants and do not enforce laws for controlling water pollution. According to [1], most cities in developing countries discharge most of their untreated sewage directly into rivers, streams and lakes. Rapid rates of urbanisation are also a characteristic of developing countries [2]. As urban centres grow spatially and demographically they are confronted by waste disposal problems which result in water pollution [3,4]. This largely contributes to the pollution of rivers traversing urban areas in most African countries resulting in the proliferation of water hyacinth (Eichhornia Crassipes) in the polluted water ways. Nutrients and temperatures are key determinants of water hyacinth growth and reproduction [5]. Daily, about 2 million tons of sewage industrial and agricultural wastes are discharged into the world's water ways [1]. These wastes introduce nutrients such as nitrates and phosphates, which create conducive environment for rapid growth of the weed $[6,7]$. In nutrient rich waters, water hyacinth grows at a fast rate that the surface it covers doubles in twelve days [8].

Water hyacinth has become a global problem with approximately 56 countries in the world including the USA struggling to remove it from water bodies [9]. In the USA, approximately 11 million dollars is spent every year in Florida, Laisan and Texas to control this weed [10]. It is especially pervasive throughout South East Asia, South USA, Central and West Africa and Southern Africa [11, 12]. According to [13], there is no clear record of how, why and when water hyacinth was introduced to water bodies outside its native range. People have been enticed to carry the weed as an ornament because of its attractive purple flower. However more important explanations for its spread can be attributed to its capacity to quickly multiply, strive and outcompete in alien lands, away from its natural predators.

Water hyacinth has spread throughout vital fresh water bodies and wetlands of Africa. Infestations of this weed are reaching crisis proportions in important fresh water bodies in Africa [14]. This is causing environmental, economic and social problems and accumulated damages that can easily be valued in the order of billions of dollars [15]. This has direct effects on communities that in one way or another depend on the environmental services or production from affected water bodies [16]. In Lake Victoria Basin, the macrophyte covers about 12,000 ha and is affecting 
livelihoods of more than 40 million people in Kenya, Tanzania and Uganda [17]. Other infested water bodies in Africa include Lake Malawi, the Zambezi River, Tano Lagoon, River Niger in West Africa, Incomati River in Mozambique, Kafue River in Zambia, Pangani River in Tanzania and Lake Naivasha in Kenya [8]. Changes to water hyacinth density have the potential to affect other ecological and human communities in areas where it is established. These changes may be perceived as positive or negative depending on the designated or beneficial uses of water body [18].

Zimbabwe has not been an exemption to the problem of water hyacinth. It is reported to have been present in Zimbabwe as early as 1940 [19] and has subsequently spread to other parts of the country. Its invasion of Lake Chivero and Manyame River has been well documented along with the resulting problems it has created [7] Shagashe River in Masvingo Province is one of the infested water ways in Zimbabwe [7]. The growth of water hyacinth in Zimbabwe is mainly attributed to the failure by councils to control water pollution by raw sewage [20].

Despite the occurrence of water hyacinth in the water bodies in Zimbabwe and specifically in the dry climates of agro-ecological region $\mathrm{V}$, its social and ecological impacts are only superficially understood. There is need to establish area specific impacts of the macrophyte in order to come up with area specific solutions. The problem of water pollution is predicted to persist given the financial and capacity challenges faced by the local authorities. Consequently, water bodies including lakes, dams and rivers have been greatly affected and are likely to continue being affected. This translates to the continuation of the existence of water hyacinth on most of the water bodies. In these affected areas are human settlements that rely on these water bodies for various economic, social, ecological services. Whether the presence of water hyacinth in water bodies is a socio-ecological blessing or curse is an issue veiled in obscurity.

Moyo et al. [7] presented an integrated management framework to control water hyacinth infestation in Shagashe River to manageable levels. Moyo and Mapira [21] tested for the effectiveness of water hyacinth in phytoremediation in Shagashe River. Another study by [22] assessed the remediation potential of selected parameters by water hyacinth. Recent literature on the management of water hyacinth mainly focuses on its removal. However, the impacts of the macrophyte to the ecological systems and surrounding communities have not yet been established. Specifically, no study has studied the socio-ecological impacts of the macrophyte along Shagashe River. It is the purpose of this study to establish the socio-ecological impacts of the water hyacinth with specific reference to Shagashe River in Masvingo through ecological assessments and social impact analysis.

\section{Materials and Methods}

\subsection{Study area}

The study was carried out in Masvingo Province along Shagashe River (Figure 1). The area is located in agroecological region five (v) of the country.The region is semi-arid with average annual rainfall below $450 \mathrm{~mm}$. It supports extensive livestock production and game ranging. The river Shagashe drains into Zimbabwe's largest 
inland water body, Lake Mtirikwi. Masvingo is a medium - sized city with a population of 88554 [23]. The city has experienced phenomenal spatial and demographic growth [24]. Water scarcity at the original site forced the city to relocate to the confluence of Mucheke and Shagashe Rivers where it has survived up to present day. The industrial activities and domestic sewage have polluted the two rivers resulting in the proliferation of water hyacinth.

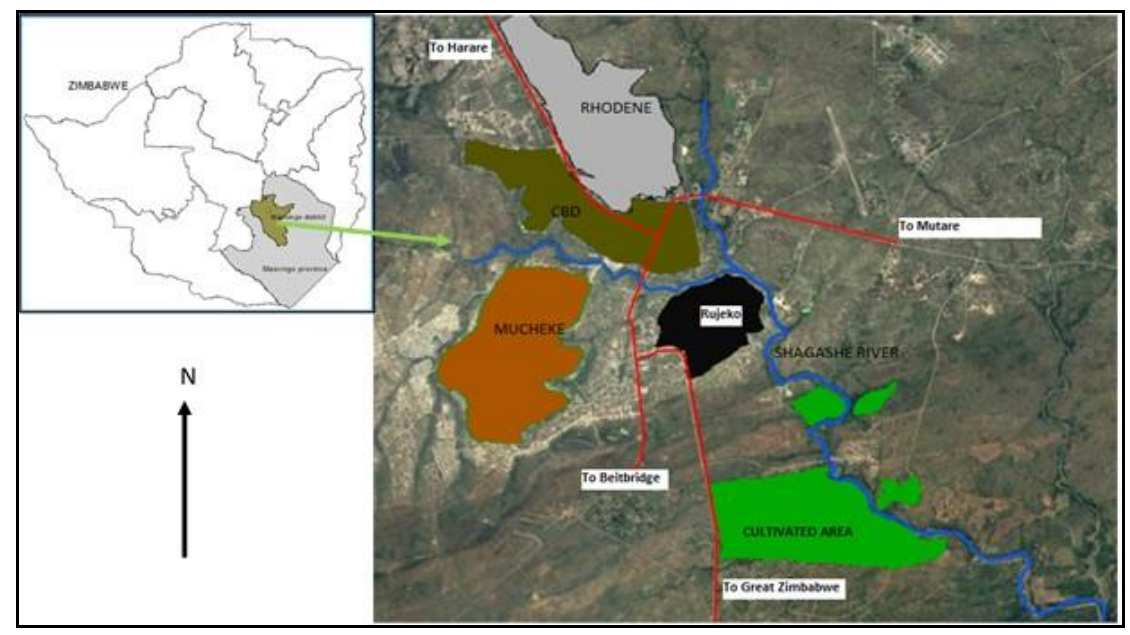

Figure 1: Location of the study area.

\subsection{Research design}

The mixed methods approach was adopted in which both qualitative and quantitative methods were used. The research required both numerical and descriptive data hence the need for combining the two methods.

\subsection{Collection of samples}

2.3.1 Water samples: Water sampling was undertaken in accordance to NWL/SAZ: 558: 1999/22/05 (sampling from surface waters) which stipulates that, samples should be taken at points where water is flowing and samples should be sterilized among other precautions [25] Water samples were collected directly from each sampling point with $500 \mathrm{ml}$ plastic containers washed with nitric acid to remove any form of contaminants. These were stored immediately in a cooler box in order to ensure that the physical properties of the water samples were maintained and transported to the laboratory for analysis. Water samples along Shagashe River were collected and analysed after every two weeks over two distinct periods; the dry season and wet season between October 2013 and August 2014. From the two periods, the same 15 sampling sites were assessed.

2.3.2 Sampling for biodiversity: The sampling frame for biodiversity measurement was determined using the species area curve as shown in Figure 2. Initially, a frame $30 * 30 \mathrm{~cm}$ in size was designed and species were counted. The size of the frame was subsequently increased to $50 * 50 \mathrm{~cm}, 80 * 80 \mathrm{~cm}, 100 * 100 \mathrm{~cm}$ up to $200 * 200 \mathrm{~cm}$. The objective was to come up with a quadrat with the optimum number of species. Figure 2 shows the species area curve used in the determination of the optimum quadrat size. The $100 * 100 \mathrm{~cm}$ quadrat had the optimum number of species. Biodiversity data was then collected from the $100 * 100 \mathrm{~cm}$ quadrats that were put in the established nine 
sampling points in each river section. Within each section, the quadrats were placed in form of a radial arm (Figure 3). The radial arm is designed to facilitate the capture of all variations within the river segment through considering 4 points. That is one from the centre, one from the N, one from the SW and the other one from the SE. Angles between arms were $120^{\circ}$ and its length $5 \mathrm{~m}$.

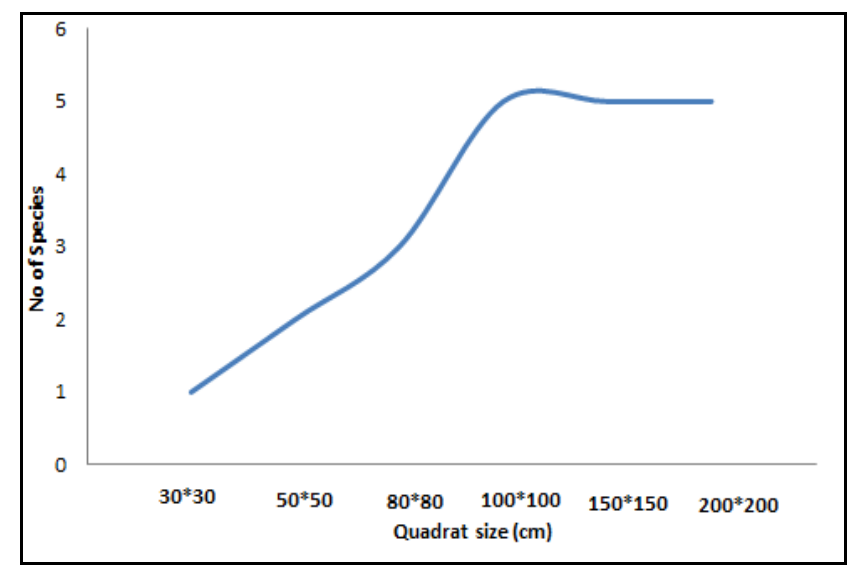

Figure 2: Species area curve.

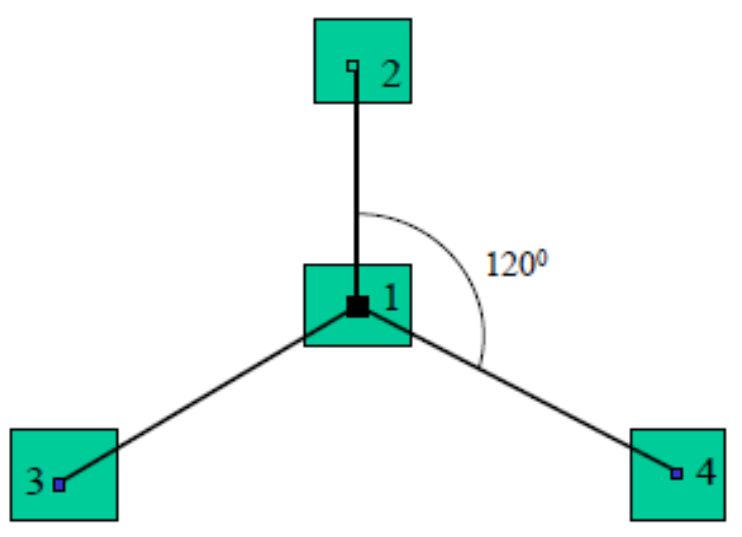

Figure 3: The radial arm.

2.3.3 Biodiversity measurements: The study assessed the influence of water hyacinth on biodiversity. To assess species diversity, the Shannon-Weaver Index, which usually combines aspects of richness and evenness $(\mathrm{H})$, was used. This method is widely recognised as a successful tool for the evaluation and quantification of plant and animal diversity, and an easy and practical measure of area diversity [26].

This index was calculated using the formula:

\section{$H=-\operatorname{Sum}\left(P_{1} \operatorname{In}\left(P_{1}\right)\right)$}

(Equation 1)

Where the summation is over all species and $P_{1}$ is the relative abundance of species in the quadrat. This index 
measures the average degree of uncertainty in predicting to what species chosen at random from a collection of $S$ species and $N$ individuals will belong (Lugwig, 1988). Species evenness (E) was also calculated using the formula:

$E=H / \operatorname{In}(S)$

(Equation 2)

Where $H$ is the Shannon Weaver index and $S$ is species richness observed within the quadrat. This index assumes that when all species in the sample are equally abundant evenness should be at maximum and decreases towards zero as the relative abundance of species diverges away from evenness [27]

2.3.4 Water testing: Water samples were collected using standard procedure as outlined in APHA Manual Water Analysis and tested using standard methods as described by the reference laboratory standard operating procedure manuals for fresh and waste water quality at University of Zimbabwe, Biological Sciences Laboratory. Fifteen samples were collected from the sampling points in the months of May and November. A total of 8 parameters were tested 4 being physical and 3 chemical. Samples were collected in 500ml clean sterilized plastic labelled containers with screw caps. The containers were rinsed several times to make sure that they are free from contaminants. Depth per each point was measured using a standard meter rule while velocity was determined using a float and stop watch. The collected samples were preserved in an ice box and transported to the lab for analysis within 24 hours. Parameters were tested to check if they are influenced by the presence or absence of water hyacinth.

\section{Experiment}

\subsection{Water evaporation experiment:}

An experiment was carried out to ascertain the effect of water hyacinth on water loss from water bodies. Water from the river was collected into evaporation pans. Evaporation pan A was filled with water and covered with live water hyacinth extracted from Shagashe River while evaporation pan B was the control pan not covered with water hyacinth. Same amount of water was put into the two pans. Assessment was done for eight days where water level was recorded from both pans after every 24 hours. This necessitated comparison of the two evaporation pans to determine the one mostly affected in terms of water loss.

\subsection{Insect infestation experiment}

We also tested whether the presence of water hyacinth attracts nuisance insects or not. The presence of insects may affect the aesthetic value of the environment and may also attract insects that cause discomfort due to biting. In this experiment, water and water hyacinth were put in pan A whilst in pan B we put water without hyacinth. Repeated observations of presence or absence of insects were done for eight days.

\subsection{Secondary data sources}

The study used previously published documents on water hyacinth in Shagashe River. Secondary information on the problem of river pollution was drawn from various sources such as Masvingo City council, ZINWA Masvingo 
branch and The Mirror, a weekly newspaper. Other sources include Environmental Management Agency data sheets on water parameters.

\subsection{Interviews}

An interview is a conversation between two people where questions are asked by the interviewer to elicit facts or statements from the interviewee [28]. Interviews were used to collect data from various stakeholders. Responsible authorities from relevant stakeholders such as Zimbabwe National Parks and Wildlife Management, Mtirikwi Sub Catchment Council and Environmental Management Agency were interviewed on information about the social and ecological impact of water hyacinth.

\subsection{Questionnaire survey}

Questionnaires were distributed in water hyacinth infested and non-infested sections for comparative purposes, a total of 50 questionnaires were distributed to collect data on social and ecological effects of water hyacinth. The questionnaires were distributed to both men and women since they have different levels of interaction with the river. People who had resided in the area for at least 5 years were targeted because they had stayed in the area long enough to notice the changes that were occurring in the river as well as felt the social impact due to the presence of water hyacinth. They also have the history of the river for the period they have stayed in the area as well as how the growth of water hyacinth has affected their various social benefits from the river.

\subsection{Observations}

In this study, observations were used to collect data. An observation guide was drafted in order to guide the researchers during data collection. Observation is a fundamental way of finding out about the world around us. Observation provides direct access to the phenomena under study. The observations were also used to assess the estimated percentage coverage of water hyacinth at selected points along the channel as well as noting the observed plant and animals present.

\subsection{Story telling approach}

Some identified people along Shagashe River were asked to tell stories related to their use of water in Shagashe River. The story telling approach captures some information that would otherwise be left out in a formal guided interview or a questionnaire survey [29]. From the stories related, important information was obtained regarding the socio-ecological impacts of water hyacinth. Stories were collected from both the area with water hyacinth and the area without water hyacinth for comparative purposes.

\section{Results and Discussions}

\subsection{Ecological impacts of water hyacinth}

4.1.1 Water loss: In this study, it was established that water hyacinth significantly affects water levels along the river. Results from a 14 day experiment shows a significant decrease $(p=0.0001, \alpha=0.05)$ in the level of water from 
water hyacinth infested pan. There is also a significant decrease $(p=0.0001, \alpha=0.05)$ in water level on the noninfested pan. Despite the fact that both pans had a significant water loss, there is a significant difference in the rate at which the two sources are losing water through evaporation and transpiration (Figure 4). Water hyacinth covered water surfaces lost water by 1.5 times more than loss from non-water hyacinth surfaces.

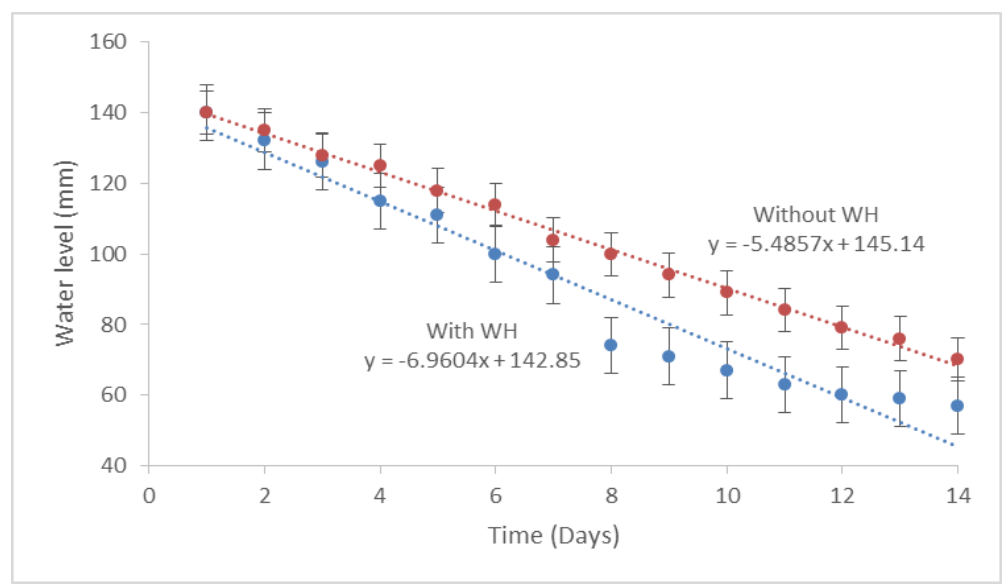

Figure 4: Water loss from water hyacinth infested and non- infested evaporation pans.

There is a significant $(\mathrm{p}=0.001, \alpha=0.05)$ difference in water loss from a water hyacinth infested and a non-infested water source. By the end of 14 days, the depth of water of the evaporation pan which contained water hyacinth had dropped from $140 \mathrm{~mm}$ to below $60 \mathrm{~mm}$. On the other hand, the evaporation pan which did not contain water hyacinth dropped from $140 \mathrm{~mm}$ to $70 \mathrm{~mm}$. The trend shows that over a long period of time the difference in the rate of water loss continues to increase. Hence, water is lost at a higher rate in water hyacinth covered water bodies as compared to open water bodies. This view was also supported by the data obtained from questionnaires where $97.3 \%$ of the respondents in the water hyacinth infested area acknowledged that they face water challenges during periods of high infestation. It is therefore the position of this study that water hyacinth results in increased rate of water loss.

Thus, water hyacinth may exacerbate ecological stress especially in the face of climate change which is marked by an increase in temperatures in the region. This may pose challenges to some aquatic species that depend on water. Hippopotamus have been reported to migrate from some sections of the river due to excessive water loss during the dry season. Several other aquatic species are likely to be affected by this water loss and this disturbs the functional dexterity of river ecosystems.

4.1.2 Biodiversity loss: Species richness data shows that during the dry season, when water hyacinth density and cover are high, plant species diversity is low. Conversely, the wet season, when water hyacinth is low, had high diversity. Figure 5 shows the difference in species richness between period of high infestation (dry season) and that of low infestation (wet season). Each sampling point was assessed twice, during the dry and wet season. 


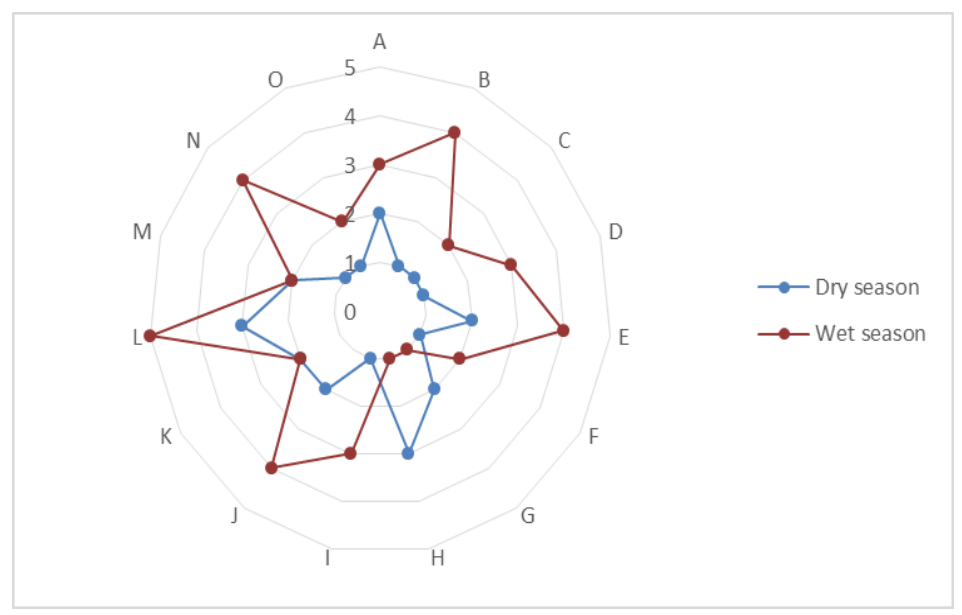

Figure 5: Differences in species richness between high water hyacinth infestation period and low infestation period.

The Shannon index of diversity calculated for the two periods also shows that diversity is high when water hyacinth cover is low or absent. This point to the fact that water hyacinth has an effect on species richness and evenness. Dry season sample quadrats had an average of 2 species including the water hyacinth whilst wet season quadrats had an average of 4 species. Thus, in terms of species richness, water hyacinth infestation is associated with low plant species diversity. In most cases where 1 species was recorded in a quadrat it was the water hyacinth weed which was mainly dominant. The macrophyte proved to be the dominant species which eliminates other water weeds.

Furthermore, calculation of species evenness has shown that the distribution of water weeds is more even where there is no water hyacinth and more uneven where there is water hyacinth. The water haycinth infested quadrats had an average of 0.19 whilst the non infested quadrats had an average of 0.73 . This shows that in terms of both richness and evenness, water hyacinth causes a decrease in biodiversity.

These findings confirm [5]'s ascertions that water hyacinth suffocates the productivity of other species, especially phytoplankton productivity. It is postulated that water hyacinth blocks sunlight from reaching lower areas within the water bodies. This affects the process of photosynthesis in other aquatic weeds and consequently affects productivity.

\subsection{Physicochemical characteristics}

As a consequence of the dense mats formed by the interlocking of individual water hyacinth plants, water quality along Shagashe River has been affected. Several water parameters (i.e. physical, chemical and biological) have ecological importance. Alteration of these parameters is associated with ecological changes. Water samples along Shagashe River were collected and analysed after every two weeks over two distinct periods; the dry season and wet season between October 2013 and August 2014. From the two periods, 15 sampling sites were assessed. Table 1 shows the results of the analyses. The values shown in Table 1 are averages of replicates taken from different samples. 


\begin{tabular}{|l|l|l|}
\hline Parameter & With high WH infestation & With no WH infestation \\
\hline Turbidity & $29.75 \pm 0.29$ & $16.89 \pm 0.85$ \\
\hline $\mathrm{pH}$ & $6.89 \pm 0.06$ & $7.54 \pm 0.05$ \\
\hline Phosphates $\left(\mathrm{mg} \mathrm{L}^{-1}\right)$ & $2.86 \pm 0.23$ & $2.42 \pm 0.20$ \\
\hline Conductivity (qus/cm) & $297.6 \pm 2.41$ & $258.5 \pm 3.98$ \\
\hline Temperature ${ }^{\circ} \mathrm{C}$ & $31.18 \pm 0.04$ & $29.32 \pm 0.51$ \\
\hline Total Nitrate $\left(\mathrm{mg} \mathrm{L}^{-1}\right)$ & $6.84 \pm 1.02$ & $11.21 \pm 1.03$ \\
\hline Total suspended solids $\left(\mathrm{mg} \mathrm{L}^{-1}\right)$ & $86.32 \pm 3.00$ & $15.93 \pm 1.08$ \\
\hline Total dissolved Oxygen & $1.72 \pm 0.30$ & $5.67 \pm 0.94$ \\
\hline
\end{tabular}

Table 1: Variations in water quality between water hyacinth infested and non-infested water in different seasons along Shagashe River. Mean value \pm S.E $(n=15)$.

Results show that during the period of maximum water hyacinth cover (May to October) the concentration of most physical parameters is high. During periods of minimum water hyacinth concentration (November to April) the concentration of the physical parameters is reduced. High density and cover of water hyacinth is associated with high levels of turbidity, conductivity, total dissolved oxygen, temperatures and $\mathrm{pH}$. It is the position of this study, however, that water hyacinth does not explain 100 percent of these parameters since there could be other factors regulating parameter level such as the dilution effect due to changes in volume and velocity.

4.2.1 Turbidity and total suspended solids: Turbidity describes the clarity and haziness of the water. From the conducted water parameter analysis, it was noted that turbidity is high in water hyacinth infested areas and season. The season of high water hyacinth density had an average of 29.75 turbidity whilst the average for the season with low or no water hyacinth had an average of 16.89 . There is a significant $(\mathrm{p}<0.05)$ difference in the levels of turbidity between these two periods. It is thus the position of this paper that water hyacinth contributes to the increase in turbidity in Shagashe River. Turbidity mostly affects growth of aquatic plants at the bottom of the water surfaces by inhibiting access to sunlight. Since plants are at the bottom of the food chain, chances of quality sustenance of the food ecosystem will be affected. Water clarity is also an indicator of potential primary productivity. High turbidity could be resulting from high sedimentation rate which is exacerbated by water hyacinth. There is high sedimentation rate within the water hyacinth's complex root structure which traps sediments and phytoplankton resulting in high turbidity. This blocks sunlight from deeper waters hence inhibiting photosynthesis which greatly reduces oxygen levels in the water. Thus, the high level of turbidity will not favour abundance of zooplankton organisms. The role of zooplankton in the energy transfer from primary producers to organisms of higher trophic levels cannot be overemphasized. It is therefore the position of this study that high turbidity resulting from the presence of water hyacinth in the river has some ecological implications.

There was also a significant difference in total suspended solids between season of water hyacinth infestation and that of low or no water hyacinth. This is due to the fact that water hyacinth mats trap detritus and phytoplankton. The suspended solids observed include silt, plankton and industrial waste. They affect aquatic ecosystems through 
clogging fish gills, reducing growth rates, decreasing resistance to disease, and preventing egg and larval development. Particles that settle out can smother fish eggs and those of aquatic insects, as well as suffocate newlyhatched larvae. The material that settles also fills the spaces between rocks and makes these microhabitats unsuitable for various aquatic insects, such as mayfly nymphs, stonefly nymphs and caddisfly larva.

4.2.2 $\mathrm{pH}$ : Results from water parameter analysis show that the presence of water hyacinth in Shagashe River contributes to the changes in water $\mathrm{pH}$. Although there is no significant difference $(p>0.05)$ between $\mathrm{pH}$ levels for the two seasons, the period with high water hyacinth density and cover has more acidic water. However, the $\mathrm{pH}$ levels for Shagashe River even during periods of high water hyacinth density are still within the natural range of between 6-8. Whilst the $\mathrm{pH}$ has not reached toxic level, the decrease poses negative consequences to the marine ecosystems through interference with life cycle of aquatic organisms. The $\mathrm{pH}$ values were generally lower for most seasons in the infested portions of the river. The water hyacinth plants can stand both highly acidic and highly alkaline conditions, but more vibrant growth is supported by neutral water bodies [30]. Water hyacinth plants do not survive in water media with $\mathrm{pH}$ equal to or less than 4.0 [31]. Given that in Shagashe River the average value for all seasons is 7 , water hyacinth is expected to proliferate.

4.2.3 Total dissolved solids: Total dissolved solids values varied in water hyacinth infested areas and open areas from the obtained results of tests conducted in May and November. In May when the sampling area had water hyacinth showed high values of total dissolved solids while November open water had a lower value. There was a significant difference in the values of total dissolved solids between water hyacinth infested areas as compared to open water areas. TDS is closely linked to turbidity and hence affect the penetration of sunlight to deeper waters.

4.2.4 Conductivity: In this study, conductivity was high in water hyacinth infested areas and in the period of high infestation. The range of values for the infested areas and period was between 290-304 $\mu \mathrm{s} \mathrm{cm}^{-1}$ while sections and the period with low or no water hyacinth values ranged between 252-264 $\mu \mathrm{s} \mathrm{cm}^{-1}$. Statistical tests reveal that conductivity in water hyacinth infested sections of the river and period was significantly higher $(\mathrm{p}<0.05)$ than sections and period with low or no water hyacinth. The implication of these results is that water hyacinth is found in areas and times when there is mineralisation and where there is high nutrient concentration. In addition, this could be due to the fact that water hyacinth contributes to the amount of salts in the water bodies since conductivity gives an estimate of salt concentration in water. Hence water hyacinth alters the conductivity of water bodies.

4.2.5 Nitrates: Nitrate concentrations are low during the period of high water hyacinth infestation. The average nitrate concentration value was $6.84 \mathrm{mg} \mathrm{L}^{-1}$ during this period. The concentrations were high during the period of low infestation with an average of $11.21 \mathrm{mg} \mathrm{L}^{-1}$. The significant difference $(\mathrm{P}<0.05)$ between these two periods could be attributed to the dilution effect which is associated with the rainy season. On the other hand, it can be attributed to the absorption of nitrates by water hyacinth. Several studies $[22,30]$ have shown that water hyacinth absorbs nitrates. As a result this indicates that, water hyacinth thrives in polluted water bodies. The macrophyte has 
a significant positive ecological impact of reducing the amount of nitrates in water bodies. From the evapotranspiration experiment, it has been noted that water hyacinth requires the provision of nitrates for it to thrive. By the end of the 14 day experiment, the invasive weed began to wilt even though water supply was kept constant. [5] note that, water hyacinth's capacity to absorb nutrients makes it a potential biological alternative to secondary and tertiary treatment for waste water.

4.2.6 Phosphates: Water hyacinth took up ammonia and nitrates preferentially to phosphates in the river as indicated by the study's results. In high water hyacinth infested areas and period phosphate concentration was found to be significantly higher than in areas and period of low or no water hyacinth infestation. According to [32] plants take up phosphates through assimilation by roots for their own growth. In this study, it seems water hyacinth has a variety of nutrients and hence favoured the uptake of ammonia and nitrates as compared to phosphates.

\subsection{Social effects of water hyacinth}

4.3.1 Physical discomfort: Results from the survey show that $74 \%$ of the respondents from questionnaires distributed in water hyacinth infested period reported the presence of mosquitoes whilst less than $30 \%$ of the respondents in the water hyacinth free period reported presence of mosquitoes. The respondents postulated that the water hyacinth weed created a favourable breeding environment for mosquitoes.

Data from the laboratory experiment confirmed the views of the respondents that water hyacinth covered areas attract more mosquitoes than areas that are not infested. In the experiment, one evaporation pan was filled with water and water hyacinth and a control evaporation pan was filled with water only. Observations of presence and absence of insects were done over a period of eight days. Results show that the water hyacinth infested pan attracted more insects, especially mosquitoes, than the water hyacinth free pan. More mosquito bites were reported in areas with more water hyacinth and high mosquito infestation. The respondents indicated that mosquito bites have been causing physical discomforts and damage to the skin which generally affects the morale of the people. Of the $74 \%$ who reported mosquito bites, $50 \%$ indicated that they live in fear of malaria infection. This indicates that the growth of water hyacinth along Shagashe River has negatively affected the people through an increase in the number of mosquito bites which cause discomfort, lack of happiness and fear of being infected with malaria.

Whilst discomfort, reduced morale and fear of being infected with Malaria are the direct social impacts of water hyacinth, this study also established that this also results in a deluge of other social problems some of which are gender based. Women are the most affected by the mosquito bites as they are the ones in constant interaction with the river ecosystem. They use the river for washing clothes, fishing and fetching water for other domestic purposes. Thus, the mosquito bites tend to be high amongst women. 
4.3.2 Reduction in aesthetic and recreational value: Results show that water hyacinth affects aesthetic and recreational value of the river to the communities along Shagashe River. While it was reported that from a distance, water hyacinth provides attractive scenery, from a close distance it releases odours and harbours insects that destroy the aesthetic and recreational value of the river. $68 \%$ of the respondents reported that their recreational activities are no longer possible with the proliferation of the macrophyte. Activities such as fishing (41\%) and swimming (36\%) have been affected significantly.

The National Parks and Wildlife Management Authority reported that Shagashe River is a major source of water into one of the country's largest inland water bodies, Lake Mtirikwi. The water hyacinth in the river is already spreading into the Lake. The authorities reported that this has had and will continue to have impacts on the recreational value of the lake. Some recreational activities such as boating are already being affected by the weed. In addition, respondents during the water hyacinth free period did not notice any changes with regards to the aesthetic and recreational value of the river. Swimming and fishing activities have not been affected. It is therefore the position of this study that water hyacinth along Shagashe River has effects on the aesthetic and recreational value of the river.

The research findings confirm the results of a similar study by [33] in Lake Victoria, Kenya, which established that water hyacinth affects recreational as well as economic activities on water surfaces. Wawire [33] highlights the impact of water hyacinth through reducing fish catches which would in turn affect household income resulting in a plethora of other social vices.

4.3.3 Threat to food security: Results from the study show that water hyacinth indirectly compromise the ability of local communities to meet their food requirements. Some communities along the river rely on irrigation agriculture of which Shagashe river is the source of water. About $40 \%$ of the respondents reported that water hyacinth has significantly clogged their irrigation pipes. This has posed some technical difficulties to the irrigation process and has seen a decline in agricultural production. A decline in agricultural production is a threat to food security to the communities along Shagashe River. The problem of clogging of irrigation pipes was not reported during the water hyacinth free period. This shows that the presence of water hyacinth in Shagashe River poses problems for agricultural production and may contribute to food insecurity.

Despite the clogging of irrigation pipes, water hyacinth has been reported by communities along the river to be influencing water loss from the river. This was also confirmed by our 14 day laboratory experiment which indicated that water hyacinth covered water surfaces tend to lose more water through transpiration than water hyacinth free water surfaces. $68 \%$ of the respondents also noted that, winter water shortages are closely linked to the presence of water hyacinth. Excessive water loss from the river has been regarded as a threat to food security especially in the face of climate change. During the dry season, water hyacinth cover is almost 100 percent in most sections of the 
river [7]. Water shortage challenges are mostly encountered this season and this has affected the local communities negatively.

4.3.4 Lack of access to clean water: More than $90 \%$ of the respondents of questionnaires distributed during the infested period noted that the proliferation of water hyacinth results in lack of debris free or clean water. $86 \%$ of the respondents also highlighted reduced access to water point. The proliferation of the invasive weed reduces accessibility to water collection points for various domestic uses such as washing, bathing and watering gardens. The reduction of water levels in the channel leads to shortages of water needed for domestic use and livestock watering. The reduction in water levels in Shagashe River may also directly affect the levels of water in Lake Mtirikwi which may later result in water shortages in the city of Masvingo since Lake Mtirikwi is the sole supplier of the water used in the city. If water hyacinth is not controlled Masvingo city may end up having severe water challenges in the near future.

All respondents from the water hyacinth free period reported deriving various social benefits of the river. They indicated that they are able to perform other domestic activities such as washing and bathing without challenges. Access of water points is not a challenge in this section. Villamagna [13] notes that water transparency is an attractive water quality in a water body that is primarily for recreation and other domestic uses.

4.3.5 Impact on religious activities: $8 \%$ of the respondents in the water hyacinth infested area indicated the effect of water loss on some religious activities such as baptism. The macrophyte inhibits the religious practice of baptism since the weed will be floating in most of the pools where the activity may be done. In order to engage in such an activity they have to travel long distances to non-infested areas. Although no respondents in the water hyacinth free section indicated that they engage in baptism events, they highlighted that if such events were to be held, no problems were going to be encountered since the water have not been affected through infestation by water hyacinth.

Generally, the water hyacinth weed has affected social lives of the community along Shagashe negatively. The community in the lower course can no longer derive benefits from the river mainly due to the growth of the invasive weed. People can no longer perform some recreational activities and reduction in the number of fish catches has affected the supplementation of their diets.

\section{Conclusion}

We conclude that, water hyacinth does more harm than good along Shagashe River both socially and ecologically. The study found that the communities along Shagashe River are exposed to a number of social problems due to the presence of water hyacinth. These include physical discomfort due to mosquito bites. The macrophyte seems to create a comfortable habitat and breeding ground of mosquitoes. The river has lost its aesthetic and recreational 
value due to the proliferation of the water hyacinth weed. Water hyacinth alters the natural state of the river. Recreational activities such as swimming and fishing are prohibited. The invasive species is one of the major threats to food security especially in the face of climate change. This worsens the situation since the region receives erratic rainfall. It exacerbates water loss resulting in communities experiencing water shortages for agricultural use especially in the dry season. Water hyacinth has also been reported to have been blocking irrigation pipes thus reducing agricultural production. Religious events such as baptism have also been reported to be affected by the presence of water hyacinth.

Ecologically, water hyacinth has been noted to have negative impacts on biological diversity. The study found out that the macrophyte reduces plant species richness and evenness in the river. In areas where the weed has proliferated some water weeds have disappeared and the water hyacinth weed become the dominant plant species. The study also found that there is a significant difference in water loss between water hyacinth and non-water hyacinth surfaces. This may pose challenges to some aquatic fauna that depend on water. One good example is the hippos which have been reported to be migrating due to decrease in water levels.

The chemical and physical parameters of water have been observed to have some ecological implications. They are also modified in a negative way due to the presence of water hyacinth. However, water hyacinth has on the other hand provided pastures to livestock of communities along the river since it will be the only green matter in the dry season. Water hyacinth is extremely difficult to eradicate once established. We recommend that the goal of most management efforts should focus on minimising socio-economic costs and ecological damage.

\section{References}

1. Miller GT, Spoolman SE. Living in the Environment: Concepts, Connections and Solutions, Brooks Cole Congage Learning, Belmont (2009).

2. UN-HABITAT. Urbanisation and Development: Emerging futures, world cities report 2016, UN Human settlements programme, Nairobi (2016).

3. Chenje M, Johnson P. Water in Southern Africa, IUCN, Harare (1996).

4. Mapira J. Urban Geography, Module 204 ZOU, Harare (2011).

5. Mironga JM, Mathooko JM, Onywere SM. Effects of Water Hyacinth Infestation on the Physico chemical Characteristics of Lake Naivasha. International Journal of Humanities and Social Science 2 (2011): 103113.

6. Chenje M. The State of the Environment in the Zambezi Basin 2000, IUCN, Harare (2000).

7. Moyo P, Chapungu L, Mudzengi B. A proposed integrated Management Approach to the control of water Hyacinth: The Case of Shagashe River in Masvingo. Greener Journal of Physical Science 3 (2013): 229240. 
8. Mailu AM. Preliminary Assessment of the Social, Economic Impacts of Water Hyacinth in the Lake Victoria Basin and the Status of Control. Australian Centre for International Agricultural Research (2001): 130-139.

9. Toft JD. Community Effects of the Non-Indigenous Aquatic Plant Water Hyacinth (Eichhornia Crassipes) in California, University of Washington, Washington DC (2000).

10. Charudattan R, Labrada R, Center TD, et al. Strategies for water hyacinth control, report of a panel of experts meeting, Fort Lauderdale, Florida, 11-14 September, 1995. Gainesville, Florida, Institute of Food and Agricultural Sciences, University of Florida (1996): 189-199.

11. Brendonck L, Maes J, Rommens W. The impact of water hyacinth (Eichhornia Crassipes) in a eutrophic subtropical impoundment (Lake Chivero, Zimbabwe). II. Species diversity Archive Fur Hydrobiologie 158 (2003): 389-405.

12. Lu JB, Wu JG, Fu ZH, et al. Water hyacinth in China: a sustainability science-based management framework. Environmental Managemen 40 (2007): 823-830.

13. Villamagna AM. The Ecological Effects of Water Hyacinth (Eichhornia Crassipes) on Lake Chapala, Mexico, PhD Thesis. Virginia Polytechnic Institute and State University, Blacksburg, Virginia (2009).

14. Kateregga E, Sterner T. Lake Victoria Fish Stocks and the Effects of Water Hyacinths on the Cathability of Fish, The Journal for Environment for Development, Discussion Paper Series 18 (2009): 62-78.

15. Toft JD. Community Effects of the Non-Indigenous Aquatic Plant Water Hyacinth (Eichhornia Crassipes) in California, University of Washington, Washington DC (2000).

16. Navarro L, Phiri G. Water Hyacinth in Africa and the Middle East International Development Research Centre, Ottawa (2000): ISBN: 9781552503676.

17. Waithaka E. Impacts of Water Hyacinth (Eichhornia Crassipes) on Fishing Communities of Lake Naivasha, Kenya. Journal on Biodiversity Endangered Species 1 (2013): 108.

18. Gibbons M, Gibbons H, Sytsma M. A Citizen's Manual for Developing Integrated Aquatic Vegetation Management Plans, in Water Environmental Services (1994).

19. Magadza CH. Management of Eutrophication in Lake Chivero, Success and failure, UZ Publications Harare (2008).

20. Chenje M, Sola M, Paleczny D. The State of Zimbabwe's Environment, Government of Zimbabwe, Harare (1998).

21. Moyo P, Mapira J. Bioremediation with the Water Hyacinth: A panacea for River Pollution in the city of Masvingo (Zimbabwe)?. Journal of Sustainable Development in Africa 14 (2012): 1520-5509.

22. Moyo P, Chapungu L, Mudzengi B. Effectiveness of water hyacinth (Eicchornia Crassipes) in remediating a polluted river. The case of Shagashe River in Masvingo, Zimbabwe, Pelagia research library, Advances in Applied Science Research 4 (2013): 55-62.

23. Zimbabwe Statistical Office (ZimStats). The 2012 Population Census: A Preliminary Report. Government Printers, Harare (2012). 
24. Scott S. Masvingo Municipality Master Plan: Draft Written Statement, Engineer's Department, Masvingo Town (1991).

25. Masere TP, Munodawafa A, Chitata T. Assessment of human impact on water quality along Manyame River. International Journal of Development and Sustainability 1 (2012): 754-765.

26. Dale VH, Offerman H, Frohn R, et al. Landscape Characterisations and Biodiversity, Research Symposium on Measuring Biological Diversity in Tropical and Temperate Areas. Proceedings of a IUFRO a Symposium held at Chiang-Mai (1994).

27. Lugwig JA, Reynolds JF. Statistical Ecology: A Primer on Methods and Computing, John Wiely and Sons, New York (1988).

28. Edwards R, Holland J. What is qualitative interviewing? Bloomsbury, London (2013).

29. Chapungu L. Effectiveness of Environmental Policy Instruments and Management Principles in Wildlife Resource Management: The Case of Mabalauta, Gonarezhou National Park, Zimbabwe, Greener Journal of Environmental Management and Public Safety 2 (2013):108-114.

30. Mironga JM. The Effects of Water Hyacinth on Phytoplankton Productivity in Lake Naivasha and the Status Control. Egerton University, Njoro (2001): 573-579.

31. Gopal B. Aquatic plant studies 1: Water hyacinth. Elsevier. Amsterdam (1987): 471.

32. Daubresse CM, Vedele FD, Dechorgnat J, et al. Nitrogen uptake, assimilation and remobilization in plants: challenges for sustainable and productive agriculture 105 (2010): 1141-1157.

33. Wawire NWO. The Impacts of Water Hyacinth (Eichhornia Crassipes ) on the Productivity, Profitability and Species Composition of the Lake Victoria Fishery, Kenya, Moi University, Eldonet (2003).

Citation: Chapungu L, Mudyazhezha OC, Mudzengi B. Socio-ecological Impacts of Water Hyacinth (Eichhornia Crassipes) Under Dry Climatic Conditions: The Case of Shagashe River in Masvingo, Zimbabwe. Journal of Environmental Science and Public Health 2 (2018): 36-52.

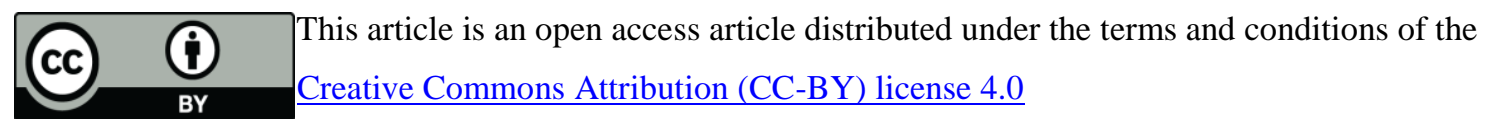

